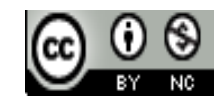

Jurnal Bimbingan Konseling Indonesia is licensed under

A Creative Commons Attribution-Non Commercial 4.0 International License.

\title{
PERAN GURU BIMBINGAN DAN KONSELING DALAM MENANGANI PERILAKU AGRESIF SISWA DI SMKN 5 SINGKAWANG
}

\author{
Bayu Sentana $^{1)}$, Slamat Fitriyadi ${ }^{2)}$, Dian Mayasari ${ }^{3)}$ \\ 1) Sekolah Tinggi Keguruan dan Ilmu Pendidikan (STKIP) Singkawang, Singkawang, Indonesia \\ E-mail: bayusentana03@gmail.com \\ 2) Sekolah Tinggi Keguruan dan Ilmu Pendidikan (STKIP) Singkawang, Singkawang, Indonesia \\ E-mail: ahmadfitriyadi521@gmail.com \\ 3) Sekolah Tinggi Keguruan dan Ilmu Pendidikan (STKIP) Singkawang, Singkawang, Indonesia \\ E-mail:diansingkawang@gmail.com
}

\begin{abstract}
Abstrak. Perilaku agresif merupakan perilaku yang dilakukan oleh individu ataupun kelompok yang dimaksudkan untuk menyakiti, melukai, dan merugikan orang lain baik individu maupun kelompok dengan niat atau kesengajaan baik secara verbal maupun nonverbal. Tujuan penelitian ini adalah untuk (1) mendeskripsikan faktor penyebab siswa berperilaku agresif di SMKN 5 Singkawang, (2) mendeskripsikan peran Guru BK dalam menangani perilaku agresif siswa di SMKN 5 Singkawang. Jenis penelitian ini adalah penelitian kualitatif dengan metode penelitian fenomenologi. Hasil penelitian ini mengenai peran Guru BK dalam menangani perilaku agresif siswa di SMK N 5 Singkawang dapat disimpulkan bahwa (1) Faktor penyebab siswa berperilaku agresif verbal adalah karena konflik antar siswa, konflik antar kelas, perbedaan pendapat, dan bosan di kelas, serta cara mengajar guru yang unik dan faktor penyebab siswa berperilaku agresif nonverbal adalah karena Frustasi, masalah dalam keluarga, nilai yang tidak tuntas, stres karena beban pelajaran dan peringkat yang turun. (2) Peran Guru BK dalam menangani siswa yang berperilaku agresif verbal adalah dengan menyelidiki permasalahan siswa tersebut, melakukan pemanggilan, menjadi mediator antar siswa dan memberikan pengarahan tentang dampak negatif dan kerugian akibat perilaku agresifnya tersebut dan peran Guru BK dalam menangani siswa yang berperilaku agresif nonverbal adalah dengan melakukan pemanggilan terhadap siswa, mencari tau permasalahannya, bekerja sama dengan Wali Kelas, melakukan pemanggilan terhadap orang tua atau wali, dan melakukan kunjungan ke rumah siswa (home visit) untuk membantu menyelesaikan permasalahannya.
\end{abstract}

Kata Kunci: Peran Guru BK; Perilaku Agresif

\section{Pendahuluan}

Sekolah adalah lembaga pendidikan formal yang dirancang untuk mendidik dan melakukan pengajaran kepada siswa sehingga siswa dapat menjadi manusia yang berkualitas sesuai dengan tujuan pendidikan nasional. Untuk menjadikan peserta didik sebagai manusia yang berguna, maka di sekolah siswa dijejali dengan berbagai ilmu pengetahuan. Selain itu siswa dididik dan diajarkan serta dibiasakan untuk berperilaku dengan baik, yaitu perilaku yang diterima oleh masyarakat. Perilaku adalah tanggapan atau reaksi individu terhadap rangsangan atau lingkungan. Tanggapan dan reaksi individu tersebut diwujudkan dalam bentuk gerak atau ucapan. Pada jenjang pendidikan menengah, baik sekolah menengah pertama maupun atas, peserta didiknya adalah individu yang berada pada usia remaja. 
Remaja adalah suatu tingkatan umur, di mana anak-anak tidak lagi menjadi anak tetapi juga belum dapat dipandang dewasa. Jadi remaja adalah usia yang merupakan masa transisi antara anak-anak dan dewasa. Pada usia ini banyak terjadi perubahan yang tidak mudah bagi seorang remaja, Mereka membutuhkan bantuan dan pengertian dari pihak orang tua maupun orang-orang dewasa. Masa ini adalah masa di mana individu belajar berinteraksi dengan masyarakat dan di dalam kehidupan sosial masyarakat dikenal bentuk tata aturan yang disebut norma. Jika tingkah laku yang diperlihatkan sesuai dengan norma yang berlaku, maka tingkah laku tersebut dinilai baik dan dapat diterima.

Masa remaja disebut juga sebagai masa pubertas. Pada masa-masa ini remaja mengalami banyak pengaruh-pengaruh dari luar yang menyebabkan Ia kesulitan untuk beradaptasi dengan lingkungan yang selalu berubah-ubah sehingga tidak semua remaja dapat berperilaku seperti yang diharapkan oleh masyarakat. Beberapa dari mereka dapat berperilaku yang maladatif, contohnya yaitu perilaku agresif yang dapat merugikan orang lain dan juga diri sendiri.

Banyak sekali insiden yang terjadi sebagai manifestasi perilaku agresif, baik secara verbal (kata-kata) maupun nonverbal (action). Saat ini, ekspose berbagai ragam perwujudan dari perilaku agresif bisa ditemukan hampir pada setiap media massa, bahkan dalam kehidupan lingkungan sehari-hari. Perwujudan dari perilaku agresif ini diantaranya mencaci maki, mengumpat, perampokan, pembunuhan, kerusuhan serta segala jenis perilaku kriminal dan tindak kekerasan.

Berdasarkan pengamatan peneliti selama satu minggu di SMK N 5 Singkawang, peneliti menemukan ada siswa yang berberilaku agresif. Perilaku agresif siswa yang sering ditemui adalah perilaku agresif yang dilakukan secara verbal dan non verbal. Verbal yaitu menggunakan kata-kata lisan seperti mengolok untuk menyakiti orang lain termasuk terhadap teman sekelas, teman di luar kelas maupun terhadap Guru. Non verbal yaitu dengan menggunakan tindakan seperti menjahili atau mengganggu teman-temanya yang sedang belajar, membuat keributan di kelas, dan menendang meja dan tong sampah. Dampak dari perilaku tersebut sangatlah mengganggu, baik bagi siswa itu sendiri maupun temantemannya karena proses belajar mengajar menjadi terganggu. Dari sinilah peran guru BK sangat diperlukan keberadaannya sebagai penunjang proses belajar dan termasuk penyesuaian diri siswa.

Tugas guru BK merupakan tugas yang sangat berat, oleh karena itu untuk melaksanakannya diperlukan adanya sikap professional dari guru BK [1]. Berdasarkan pada kenyataan tersebut, maka peneliti tertarik untuk mengetahui lebih dalam tentang peran Guru BK dalam menangani perilaku agresif siswa di SMK N 5 Singkawang.

\section{METODE}

Penelitian ini merupakan salah satu jenis metode kualitatif, dimana peneliti mencoba menjelaskan atau mengungkap makna konsep atau fenomena pengalaman yang didasari oleh kesadaran yang terjadi pada beberapa individu. Fenomenologi dilakukan dalam situasi yang alami, sehingga tidak ada batasan dalam memaknai atau memahami fenomena yang dikaji dan peneliti bebas untuk menganalisi data yang diperoleh.

Menurut Creswell [2], pendekatan fenomenologi menunda semua penilaian tentang sikap yang alami sampai ditemukan dasar tertentu. Penundaan ini biasa disebut epoche (jangka waktu). Konsep epoche adalah membedakan wilayah data (subjek) dengan interpretasi peneliti. Konsep epoche menjadi pusat dimana peneliti menyusun dan mengelompokkan dugaan awal tentang fenomena untuk mengerti tentang apa yang dikatakan oleh responden.

Penelitian di laksanakan pada Juli - Agustus 2017 dengan rincian jadwal sebagai berikut:

a. 28-3 Agustus

Observasi di Sekolah Menengah Kejuruan Negeri (SMKN) 5 Singkawang, observasi dilakukan terhadap siswa dan Guru BK.

b. 4-5 Agustus

Wawancara terhadap sejumlah siswa tanpa pemberitahuan kepada siswa tersebut bahwa mereka sedang di teliti.

c. 6-7 Agustus

Wawancara terhadap Guru BK dan Wali Kelas berkaitan dengan bentuk-bentuk perilaku agresif siswa dan penanganannya serta cara pemberian layanan Guru BK dalam mengatasi perilaku agresif siswa.

Moleong [3] mendeskripsikan subjek penelitian sebagai informan, yang artinya orang pada latar penelitian yang dimanfaatkan untuk memberikan informasi tentang situasi dan kondisi latar penelitian. Subjek dalam penelitian ini yaitu Guru BK yang memberikan layanan Bimbingan dan Konseling di SMK N 5. Objek penelitian penelitian ini adalah para siswa SMK N 5 kelas XII MM yang berjumlah 44 siswa dan TPHP yang berjumlah 38 siswa dan siswa-siswi yang berperilaku agresif.

Pengumpulan data di mulai dengan penentuan sekolah yang akan di teliti, kemudian menentukan Guru BK untuk di observasi dan wawancara. Beberapa metode pengumpulan data yang digunakan adalah:

a. Observasi

Observasi adalah teknik pengumpulan data, melalui observasi peneliti belajar tentang perilaku dan makna dari perilaku tersebut (Marshall, dalam[4]). Dalam melakukan observasi ini peneliti langsung ke tempat penelitian untuk mengamati bagaimana bentuk-bentuk perilaku agresif siswa di SMK N 5 dan mengamati bagaimana peran yang dilakukan oleh Guru BK dalam melakukan layanan BK terkait kasus tersebut.

b. Wawancara

Wawancara dilakukan setelah melakukan observasi. Wawancara merupakan pertemuan dua orang untuk bertukar informasi dan ide melalui tanya jawab sehingga dapat dikonstruksikan makna dalam satu topik tertentu (Esterberg, dalam [4]). Dalam wawancara ini peneliti mewawancarai beberapa siswa dan Guru BK untuk mendapatkan informasi tentang bentuk-bentuk perilaku agresif yang sering mereka temui baik yang verbal maupun non verbal, dan faktor penyebabnya. 
Wawancara terhadap Guru BK yaitu untuk mendapatkan informasi tentang faktor penyebab siswa perilaku agresif, dan peran Guru BK dalam menanganinya. adalah:

Tahap yang dilakukan dalam analisis data model ini

\section{a. Analisis Domain}

Yaitu untuk memperoleh gambaran yang umum dan menyeluruh dari objek penelitian ataupun situasi sosial. Peneliti menetapkan domain tertentu sebagai pijakan untuk penelitian selanjutnya. Domain yang dimaksud di sini adalah Guru dan Siswa. Guru meliputi Guru BK, Wali Kelas, dan Guru Mapel. Siswa meliputi siswa kelas 1,2 dan 3 baik MM (Multimedia) maupun TPHP (Teknik Pengolahan Hasil Perkebunan).

b. Analisis Taksonomi

Yaitu domain yang dipilih tersebut selanjutnya dijabarkan menjadi lebih rinci, untuk mengetahui struktur internalnya, maka dilakukan observasi terfokus.

c. Analisis Tema

Yaitu mencari "benang merah", yaitu hubungan di antara domain, dan selanjutnya dinyatakan ke dalam tema/judul penelitian.

\section{HASIL DAN PEMBAHASAN}

A. Hasil

1. Faktor Penyebab Perilaku Agresif Siswa di SMK N 5 Singkawang

Berdasarkan hasil observasi yang dilakukan oleh peneliti, perilaku agresif yang ada di SMK N 5 adalah dalam bentuk verbal dan non verbal. Perilaku agresif Verbal yang ditemui di sekolah adalah menggunakan kata-kata lisan untuk mengolok dengan tujuan untuk menyakiti orang lain termasuk terhadap teman sekelas, teman di luar kelas dan terhadap Guru. Sedangkan perilaku agresif nonverbal yang terjadi adalah mengganggu dan menjahili teman yang sedang belajar, menendang meja dan menendang tong sampah.

Dari hasil wawancara peneliti kepada siswa, faktor penyebab perilaku agresif adalah:

a. Perilaku Agresif Verbal (mengolok teman sekelas, teman di luar kelas, dan Guru)

1. Mengolok teman sekelas, faktor penyebabnya adalah siswa merasa bosan di kelas karena tidak ada guru, adanya konflik antar siswa, adanya perbedaan pendapat dalam mengambil keputusan untuk kegiatan kelas.

2. Mengolok teman di luar kelas, faktor penyebabnya adalah karena adanya konflik antar kelas akibat kegiatan antar kelas, adanya konflik perorangan antar siswa dari kelas yang berbeda, serta rebutan jadwal pelajaran (yaitu salah satu kelas menginginkan jadwal pagi, tapi kelas lain telah memilih jadwal pagi terlebih dahulu).

3. Mengolok guru, faktor penyebabnya adalah karena kebiasaan guru yang unik seperti tidak tepat waktu dan cara mengajarnya yang tidak biasa, sering bercerita saat mengajar dan karena sering mengeluarkan candaan yang kelewatan saat mengajar di dalam kelas.

b. Perilaku Agresif non verbal

1. Menjahili teman dan mengganggu teman yang sedang belajar, faktor penyebabnya adalah karena siswa tersebut ingin mendapat perhatian dari temantemannya, stress yang disebabkan tugas menumpuk pada mata pelajaran yang tidak disukai, merasa ngantuk dan bosan sehingga bermaksud untuk menghilangkan kantuknya dengan menjahili temannya.

2. Menendang meja/tong sampah, faktor penyebabnya adalah karena siswa tersebut merasa kesal dengan apa yang terjadi di rumahnya sehingga mengganggu pikirannya hingga ke sekolah dan melampiaskan kekesalannya pada meja atau tong sampah, merasa frustasi dan stress yang disebabkan tugas yang menumpuk pada mata pelajaran yang tidak disukai.

Wawancara yang peneliti lakukan kepada Guru BK diperoleh hasil sebagai berikut:

a. Perilaku Agresif Verbal

1. Mengolok teman sekelas, faktor penyebabnya adalah karena konflik pribadi seperti pernah bertengkar sebelumnya

2. Mengolok teman di luar kelas, faktor penyebabnya adalah karena siswa tersebut pernah terlibat konflik dengan teman di luar kelas akibat kegiatan antar kelas.

3. Mengolok Guru, faktor penyebabnya adalah karena siswa tidak menyukai cara guru yang tersebut dalam mengajar di kelas.

b. Perilaku Agresif Non Verbal

Berdasarkan hasil wawancara terhadadap Guru BK, faktor yang menyebabkan siswa berperilaku agresif non verbal adalah:

1. Menjahili teman dan mengganggu teman yang sedang belajar, faktor penyebabnya adalah karena siswa bosan dikelas dan mencari hiburan, karena siswa tersebut merasa cemburu karena persaingan nilai, dan karena jam pelajaran kosong yang disebabkan gurunya tidak masuk kelas.

2. Menendang meja atau tong sampah, faktor penyebabnya adalah karena siswa merasa frustasi dengan masalah yang terjadi di rumah, masalah yang terjadi dengan teman di sekolah, stress karena tuntutan belajar dengan kkm yang tinggi, lingkungan sekolah yang membuat stress, marah dan kecewa karena nilai dan rangking yang mengalami penurunan.

\section{Peran Guru BK Dalam Menangani Siswa Yang} Berperilaku Agresif

Berdasarkan hasil observasi yang dilakukan oleh peneliti, peran guru BK dalam menangani siswa yang berperilaku agresif adalah:

a. Perilaku Agresif Verbal

Yaitu dengan melakukan penyelidikan terhadap kasus tersebut, kemudian melakukan pemanggilan terhadap siswa yang menggunakan kata-kata lisan seperti 
mengolok untuk menyakiti orang lain termasuk terhadap teman sekelas, teman di luar kelas maupun terhadap Guru untuk diberi penjelasan dan pengertian tentang dampak negatif dan kerugiannya apabila terus melakukan perilaku agresif verbal tersebut. Untuk perilaku agresif verbal yang terjadi akibat adanya konflik antar siswa, maka Guru BK akan menjadi mediator serta membantu untuk menyelesaikan permasalahannya. Dan untuk perilaku agresif yang disebabkan oleh konflik antar kelas, maka Guru BK akan menjadi mediator dengan melibatkan wali kelas untuk menyelesaikan konflik antar kelas tersebut.

b. Perilaku Agresif Non Verbal

Peran Guru BK dalam menangani perilaku agresif nonverbal ini yaitu dengan melakukan peanggilan terhadap siswa yang menggunakan tindakan seperti menjahili atau mengganggu teman-temanya yang sedang belajar, dan yang menendang meja atau tong sampah saat marah atau frustasi untuk dicari tau permasalahannya. Bila permasalahannya menyangkut pelajaran dan kegiatan di sekolah, maka Guru BK akan berusaha menyelesaikan permasalahannya dengan pihak sekolah terutama dengan wali kelas dan guru mata pelajaran. Namun bila permasalahannya berada dalam lingkungan keluarga, maka Guru BK akan melakukan kunjungan rumah untuk melihat keadan siswa di rumahnya.

Sedangkan berdasarkan hasil wawancara terhadap Guru BK, maka yang dilakukan oleh Guru BK dalam menangani perilaku siswa yang berperilaku agresif, Guru BK harus memiliki sebuah dasar atau data tentang bagaimana siswa tersebut berperilaku agresif dan mengetahui perilaku agresif apa yang dilakukan oleh siswa. Guru BK harus mencari tau sendiri tentang perilaku siswa yang bersangkutan, yaitu dengan cara menanyakan kepada teman terdekat atau teman sekelas apa perilaku agresif seperti apa yang dilakukan oleh siswa tersebut, verbal atau non verbal dan mencari tau penyebab kenapa siswa tersebut melakukan perilaku agresif tersebut. Guru BK juga bekerja sama dengan wali kelas untuk mengetahui mengapa siswa tersebut bereperilaku agresif, bekerja sama dengan Guru Mata Pelajaran dan selanjutnya melakukan pemanggilan terhadap orang tua dan juga kunjungan rumah untuk mengetahui permasalahan yang dihadapi siswa dalam keluarganya.

\section{B. Pembahasan}

Terdapat banyak faktor yang menyebabkan siswa dapat berperilaku agresif verbal di SMK N 5 Singkawang, diantaranya adalah karena bosan di kelas, karena cara guru mengajar, karena kebiasaan guru yang negatif, karena konflik pribadi antar siswa maupun antar kelas. Sedangkan faktor yang menyebabkan siswa berberilaku agresif non verbal adalah karena frustasi, stres karena pelajaran, dan karena adanya masalah dalam keluarga serta lingkungan belajar yang membuat stres. Hal ini sesuai dengan pendapat Taylor, Peplau, \& Sears [5] yang mengatakan bahwa salah satu faktor yang menyebabkan seseorang berperilaku agresif adalah frustasi. Demikian juga menurut Myers [6] yang menyatakan bahwa penyebab perilaklu agresif pada seseorang adalah karena faktor lingkungan.

Peran Guru BK di SMK N 5 dalam menangani siswa yang berperilaku agresif adalah dengan melakukan observasi terhadap siswa yang berperilaku agresif dan juga temantemannya, melakukan pemanggilan terhadap siswa yang bersangkutan untuk mencari tau masalahnya dan bekerja sama dengan wali kelas dan melakukan pemanggilan terhadap orang tua atau wali agar permasalahan siswa dapat terselesaikan. Hal ini juga sejalan dengan hasil penelitian Putra [1] yang mengatakan bahwa peran guru BK dalam menurunkan perilaku agresif adalah peserta didik yang menunjukkan kecenderungan untuk berperilaku agresif dipanggil ke ruang BK, diberi pengarahan, dan nasehat agar mengubah perilakunya tersebut, kemudian Guru BK memberikan penjelasan bahwa perilaku yang peserta didik lakukan dapat menyakiti dan merugikan orang lain maupun dirinya sendiri.

Peran yang dilakukan oleh Guru BK tersebut adalah peran yang bersifat kuratif, hal ini dinyatakan oleh Salahudin [7] yang mengatakan bahwa salah satu peran Guru BK adalah Menyelenggarakan bimbingan terhadap siswa, baik yang bersifat preventif, preservatif, korektif dan kuratif. Hal yang dilakukan oleh Guru BK adalah tersebut adalah peran yang bersifat kuratif, yaitu menyelesaikan permasalahan yang telah terjadi.

\section{KESIMPULAN}

Hasil penelitian mengenai peran Guru BK dalam menangani perilaku agresif siswa di SMK N 5 Singkawang adalah

1. Faktor penyebab siswa berperilaku agresif

a. Verbal, faktor penyebabnya adalah karena konflik antar siswa, konflik antar kelas, perbedaan pendapat, dan bosan di kelas, serta cara mengajar guru yang unik.

b. Nonverbal, faktor penyebabnya adalah karena Frustasi, masalah dalam keluarga, nilai yang tidak tuntas, stres karena beban pelajaran dan peringkat yang turun.

2. Peran Guru BK dalam menangani siswa yang berperilaku agresif

a. Verbal, peran Guru BK dalam menanganinya adalah dengan menyelidiki permasalahan siswa tersebut, melakukan pemanggilan, menjadi mediator antar siswa dan memberikan pengarahan tentang dampak negatif dan kerugian akibat perilaku agresifnya tersebut.

b. Perilaku agresif nonverbal, Peran Guru BK dalam menanganinya adalah dengan melakukan pemanggilan terhadap siswa, mencari tau permasalahannya, bekerja sama dengan Wali Kelas, melakukan pemanggilan terhadap orang tua atau wali, dan melakukan kunjungan ke rumah siswa (home visit) untuk membantu menyelesaikan permasalahannya. 


\section{DAFTAR PUSTAKA}

[1] Putra, A. R. B. (2015). Peran Guru Bimbingan dan Konseling Dalam Mengatasi Kecenderungan Perilaku Peserta Didik di SMKN 2 Palangka Raya. Jurnal Konseling GUSJIGANG, 1 (2).

[2] Creswell, J. W. (1998). Qualitative Inquiry and Research Design: Choosing Among Five Traditions. California: Sage Publication.

[3] Moleong, L. (2010). Metode Penelitian Kualitatif. Bandung: Remaja Rosda Karya.

[4] Sugiyono. (2010). Metode Penelitian Kuantitatif, Kualitatif, dan R\&D. Bandung: Alfabeta.
[5] Taylor, S. E., Peplau, L. A., \& Sears, D. O. (2009). Psikologi Sosial. Jakarta: Kencana Prenada Media Group.

[6] Myers, D. G. (2002). Social Psychology. $7^{\text {th }}$ edition. New York: McGraw Hill.

[7] Salahudin, A. (2010). Bimbingan \& Konseling. Cet.1. Bandung: CV. Pustaka Setia. 